\title{
Evaluation of the Status of Natural Habitat Restoration in the Liao River's Riparian Zone
}

\author{
Su Chen ${ }^{1 *}$, Ying Chen ${ }^{1}$, Tianzhen Feng ${ }^{1}$, Lei Chao ${ }^{2}$ \\ ${ }^{1}$ Key Laboratory of Regional Environment and Eco-Remediation (Ministry of Education), \\ Shenyang University, Shenyang, 110044, China \\ ${ }^{2}$ College of Municipal and Environmental Engineering, Shenyang Jianzhu University, Shenyang, 110168, China
}

Received: 18 September 2020

Accepted: 1 November 2020

\begin{abstract}
In order to clarify the restoration status of natural habitat in riparian zone of Liao River Conservation Area, promote the healthy management of riparian zone ecosystem of Liao River Conservation area, and realize the sustainable development of river and regional ecosystem, this paper build a practical and feasible evaluation index system and formulate appropriate evaluation criteria by combining geographical features with its natural and artificial factors. The comprehensive index method was used to evaluate the restoration status of natural habitats in the riparian zone of Liao River reserve. The results show that, $21.74 \%$ of the sampling sites were in excellent condition, $17.39 \%$ in good condition, $26.09 \%$ in general condition, $17.39 \%$ in worse condition, and $17.39 \%$ in very bad condition. Compared with historical data, $82.61 \%$ of riparian natural habitats were improved, while only $17.39 \%$ of riparian natural habitats remained unchanged. There was no degradation of natural habitats in riparian zones, and natural habitats in riparian zones in the Liao River reserve were in a state of recovery.
\end{abstract}

Keywords: natural habitat restoration, Liao River's riparian zone, evaluation

\section{Introduction}

Riparian habitat is a key element of river function. It is not only the environment for various organisms in riparian zones, but also an important factor for maintaining ecosystem integrity and river health in these zones [1-2]. In recent years, the impact of human activities on nature has been increasing, and threats to the habitat function of riparian zones has become increasingly serious [3]. When faced with global change, protecting riparian zones of rivers, preventing their

*e-mail: mailchensu@aliyun.com degradation, and restoring ecosystems is a challenging task [4].

According to the functions of riparian zone habitat that is comprised of the rivers, land, and animals on both sides of its border, the restoration status of its natural environment can be used to assess its function and value when evaluating natural habitat restoration. Recognition of natural habitats on the basis of investigation and zone habitat conditions can use appropriate methods to evaluate the riparian zone status of natural habitats in order to determine how these zones restore the status quo and insufficiency, helps identify the root cause of the river banks' natural habitat degradation, and provides an important basis for river ecosystem restoration and management. Assessment of riparian 
habitats helps identify the causes of habitat degradation, which is essential for achieving and maintaining good river health and maintaining the ecological functions provided by riparian areas [5].

At present, there is more existing overseas research on riparian habitat evaluation, including evaluation research on rivers or river banks that involves typical evaluation methods such as the river habitat survey (RHS), the US' rapid biological assessment scheme (RBP) and riparian quality index (RQI), Australia's index of stream condition (ISC), as well as Spain's riparian forest quality index (QBR) [6-8]. Grizzetti et al. proposed the evaluation of ecosystem services related to aquatic ecosystems on a European scale, and analyzed the relationship between ecosystem conditions and services [9]. Janssen et al. pointed out that riparian habitats are transitional zones of communities formed by strong environmental gradients. They evaluated the effects of elevation and soil texture gradients on the functional composition of riparian plants by studying a highly degraded river, and evaluated the effects of maintenance and restoration measures on riparian community structure. Their evaluation results can effectively promote habitat restoration in a river's riparian zone [10].

In the study of evaluation indicators, Rowntree selected river invertebrates, riparian vegetation, habitat integrity, water quality and other indicators to evaluate the health status of rivers [11]. Meng et al. developed a habitat evaluation index considering ten parameters of characteristics of the north river ecosystem in China (substrate, habitat complexity, speed-depth combination, river bank stability, bank protection, vegetation coverage, vegetation diversity, cognitive and riverside land use, intensity of human activities, and water) and on the basis of improved Barbour system [12]. In related studies, biological indicators are considered to play an important role in the assessment of riparian habitat, which mainly include plant, microbial, and animal indicators [13]. Biological indicators are considered to correctly evaluate riparian ecosystems. Hale et al. explained that the recovery of riparian zones can prevent or reverse their degradation. In order to avoid the loss of ecosystem function that these zones provide, Hale et al. used field tests and evaluated the riparian zone of southeastern Australia rivers in order to further understand their vegetation and soil restoration [14]. Diehl et al. by developing a modeling framework to assess the impact of riparian ecosystems on river function, predicted the presence of riparian plant communities, amount of vegetation cover, and impact of topography on rivers [15]. Blumetto et al. established the ecosystem integrity index (EII), which includes vegetation structure, plant species, soil and riverbank, to evaluate specific ecosystems [16]. Many studies have evaluated rivers or riparian zones by establishing the macroinvertebrate index of biological integrity (MIBI), which can provide necessary information for effectively managing river ecosystems [17].
Research on riparian habitat evaluation started late in China and it lacks a well-developed evaluation index and method for evaluating riparian habitat. In order to eliminate uncertainty of river assessment in their study, Wang et al. made more objective weights for evaluation indexes, and used integrated rough centralized model as an improved method to determine the weights of evaluation indexes. They combined it with the improved gray correlation model constructed using the comprehensive evaluation model's physical conditions of habitat, chemical and biological structure in the Wei River Basin as an example for the evaluation of river ecosystem [18]. Fu et al. evaluated riparian zone status by establishing physical structural integrity (PSI). According to the actual characteristics of rivers in the study area; Liu et al. established a river habitat evaluation index suitable for the section of the Lake Tai Basin near the city of Yixing, and evaluated the habitats of 42 sampling sites [19, 20].

At present, China's evaluation of natural habitat restoration in riparian zones is still in its primary stage, and China lacks a unified evaluation index that can be applied to riparian habitat evaluation in specific regions. Therefore, it is necessary to construct a complete evaluation index of riparian zone habitat and the theoretical framework and system of evaluation methods in order to improve the evaluation of natural habitat status of riparian zones in China and promote health management and development of riparian zone ecosystems. In recent years, comprehensive management has significantly increased the biodiversity of the riparian zone of the Liao River's main stream. Its natural habitat has also improved, but many factors are still affecting and limiting the restoration of natural habitat in its riparian zone. In order to further improve the natural habitat of the riparian zone in the Liao River's reserve, this paper, based on regional characteristics, as well as natural and human factors, starts with characteristics of riparian zone habitat, the analytic hierarchy process (AHP) was used to determine the weight of evaluation index, and the comprehensive index method was used to evaluate the status quo of natural habitat restoration in the riparian zone of the Liao River's reserve. Clarifying the current state of natural habitat restoration in the riparian zone of Liao River reserve provides an important basis for its health management and has important practical significance.

Based on this, the purposes of the present study are to: (1) To establish an evaluation index of natural habitat restoration in the riparian zone of the Liao River's reserve, and formulate appropriate evaluation criteria for natural habitat restoration in this riparian zone; (2) To assess the status quo of natural habitat restoration in this riparian zone, compare it with historical data sets to understand the influencing factors of natural habitat degradation in this riparian zone, and clarify the status quo of natural habitat restoration in this riparian zone; (3) To provide a theoretical basis and reference 
significance for habitat restoration and ecological management in the Liao River's reserve.

\section{Materials and Methods}

\section{Study Area}

The Liao River originates from Fudedian, Changtu County, Tieling City, Liaoning Province, China, and ends at the mouth of Panjin Red Beach, with a total length of about $538 \mathrm{~km}$, passing through four cities including Tieling, Shenyang, Anshan and Panjin. It is one of the most important rivers in Liaoning Province [21].

In recent years, with the comprehensive improvement of the Liao River Basin's ecosystem, this river's water quality has been greatly improved. Moreover, technology such as the $12^{\text {th }}$ Five-Year Plan's special Liao River water training and comprehensive repair, nature cultivation, and implementation of ecosystem restoration for riparian zones have improved the Liao River area's natural habitat. However, due to geographical characteristics and the influence of natural and artificial factors, during the natural habitat recovery process, many new problems or influencing factors, as well as obstacles to its continued recovery process, have tended to appear. Based on this and on the research of the $12^{\text {th }}$ Five-Year Plan, it is urgent to evaluate the restoration status of natural habitats in the riparian zone of the Liao River's reserve.
According to the basin and other characteristics of the Liao River's reserve, a total of 23 sampling points were selected in this study to evaluate natural habitat restoration in its riparian zone. The distribution diagram of sampling points is shown in Fig. 1.

\section{Constructing an Evaluation Index}

Principles for constructing an index: (1) Representativeness: In the process of research and evaluation, the principles of hydraulics and ecology should be followed, and the decisive indexes that can reflect the basic characteristics of riparian habitat should be selected from many influencing factors. The selected indicator factors should be representative to reflect the characteristics of riparian habitat restoration in Liao River reserve. (2) Pertinence: Riparian habitats tend to be relatively single, are subject to more human interference and influence, and also take on more functions and uses. The Liao River's regional characteristics and natural factors must be considered when constructing the index. (3) Comparability: All indicators should have relatively consistent collection and calculation methods, and evaluation results of riparian zones under different conditions should also be comparable. (4) Operability: The meaning of indicators must be clear and independent, and their standards should not be different due to different understandings of evaluation indicators, which can result in errors in evaluation results. The index data used for evaluation should be easy to collect and process, and both

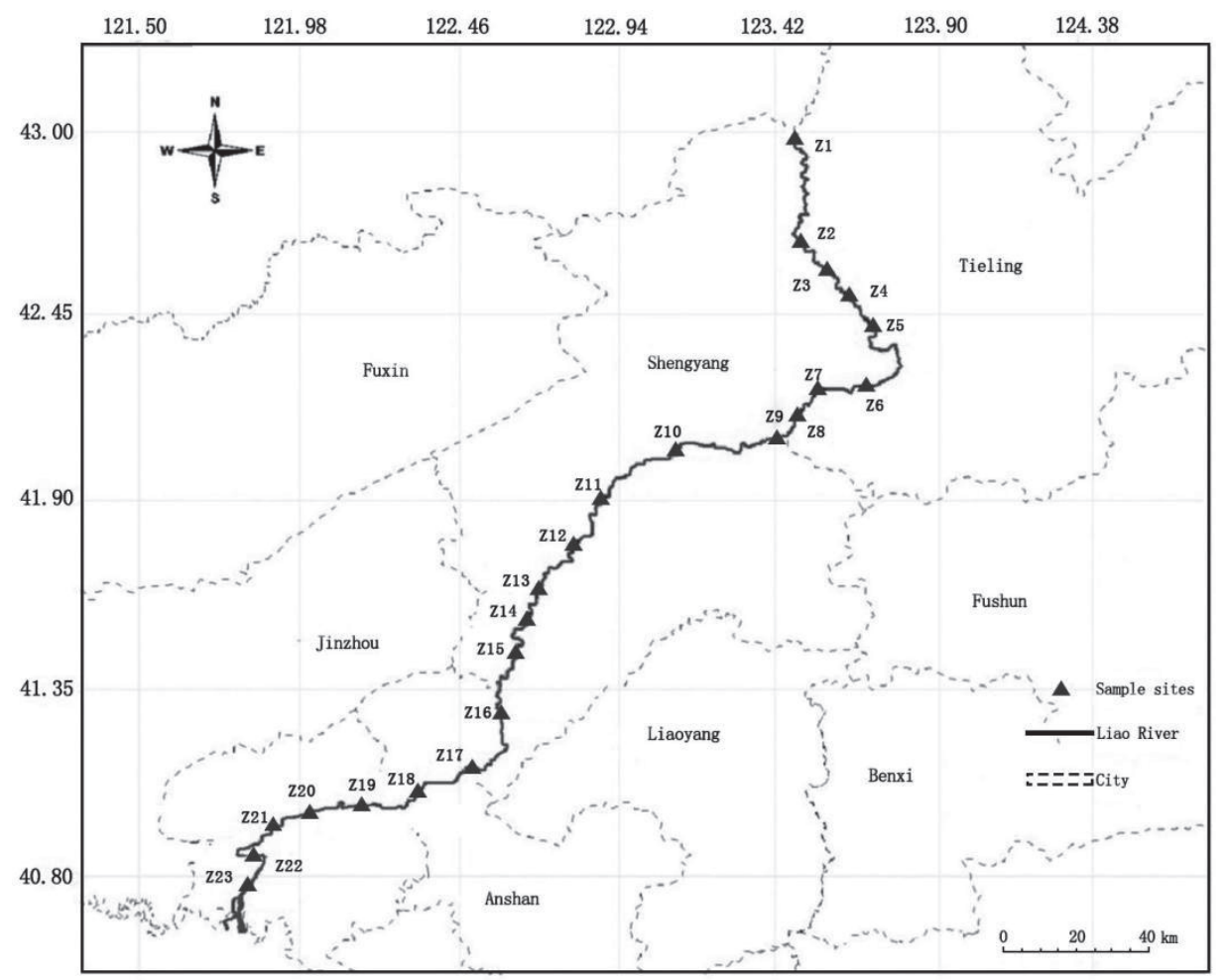

Fig. 1. Distribution of sampling points in Liao River reserve. 
qualitative description and quantitative measurement should be taken into account. (5) Comprehensive: Influencing factors of riparian habitat restoration includes many aspects. The indicators should cover many aspects that affect riparian habitat restoration, including vegetation cover, traditional hydrology, soil characteristics, land use, cultural landscape and social functions. (6) Scale: The designed indicator system is suitable for habitat evaluation in the riparian zone. Macro and micro indicators should be combined when constructing the indicator system to comprehensively reflect the characteristics of habitat restoration in the riparian zone. (7) Predictability: The selected indicators should be predictable, and future trends of riparian habitat can be predicted according to evaluation results of different stages.

\section{Screening and Determination of Evaluation Indicators}

Reserves in the Liao River with natural habitat restoration evaluation is the goal layer, the function of the riparian zone's natural habitat is the criterion layer, the criterion layer and characteristics of shadows and factors is the index layer, and a layered index of various indexes corresponds to the criterion layer of the influencing index factors, which are refined into several indicators (Hierarchical chart of the evaluation index for the Liao River reserve's natural habitat restoration in its riparian zone is shown in Fig. 2). This evaluation index is preliminarily determined based on the definition of riparian zones' natural habitats, and combined with Chinese and overseas river and riparian zone evaluation, related literature and data from river banks that is intended to promote stability in natural habitats, buffering function, service function, and main factors of biodiversity. This evaluation index is finally determined by using SPSS18.0 to apply principal component analysis to select its individual components.

\section{Evaluation Criteria}

The assessment of the status of natural habitat restoration in the riparian zone of the Liao River's reserve is based on the hierarchy, classification and criteria of evaluation indicators. According to the evaluation index of natural habitat restoration in riparian zones, the indicators of its stabilization function, buffering function, service function and biodiversity are shown in Table 1, Table 2, Table 3 and Table 4, respectively [22-24]. The evaluation criterion has five evaluation grades: excellent, good, medium, worse and bad.

\section{Acquisition and Test of Evaluation Indexes}

The types of bank slopes, stability of banks, stability of river beds, bottom quality, width of bank zones, river curvature, topography connectivity, activities mainly affected by human activities, abundance of recreational facilities, corridor connectivity, grazing conditions and vegetation coverage were obtained through field surveys.

Plaque fragmentation index:

$$
F=\frac{N_{P}-1}{N_{C}}
$$

...where $\mathrm{F}$ is the plaque fragmentation index, $\mathrm{N}_{\mathrm{p}}$ is the total number of landscape patches in the measured area and $\mathrm{N}_{\mathrm{C}}$ is the ratio of the total area to the minimum patch area.

Index calculation method of wetland retention:

$$
\text { Wetland retention }=\frac{\text { Watershed wetland area }}{\text { Basin area }} \times 100 \%
$$

Water $\mathrm{NH}_{3}-\mathrm{N}$, water TP: Hanna COD speedometer (HI83224);

Index Level

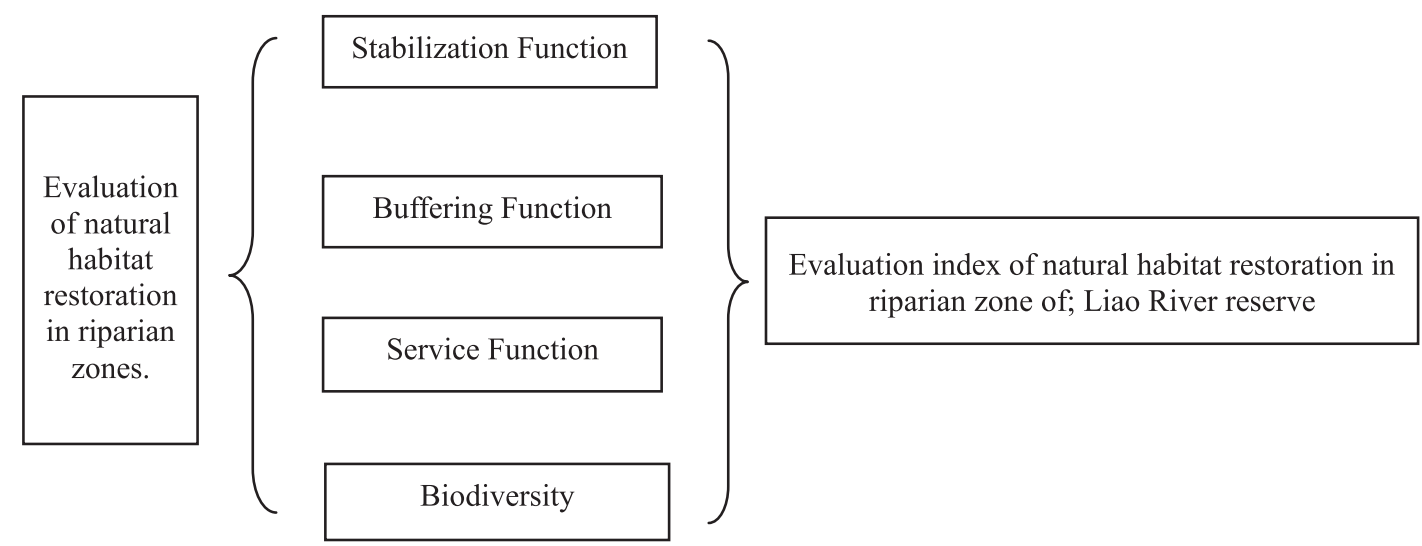

Fig. 2. Hierarchical chart of the evaluation index for the Liao River reserve's natural habitat restoration in its riparian zone. 
Table 1. Criteria for evaluating the stability function of natural habitats in riparian zones.

\begin{tabular}{|c|c|c|c|c|c|c|}
\hline \multirow{2}{*}{ Parameters } & \multicolumn{5}{|c|}{ Evaluation Criterion } & \multirow{2}{*}{ Reference } \\
\hline & Excellent & Good & Medium & Worse & $\mathrm{Bad}$ & \\
\hline $\begin{array}{l}\text { Bank slope } \\
\text { type }\end{array}$ & Natural prototype & Close to nature & $\begin{array}{c}\text { Riprap, low retaining } \\
\text { wall, } \\
\text { concrete grid vegetation }\end{array}$ & $\begin{array}{l}\text { Pile stone, } \\
\text { slurry stone } \\
\text { block, dry } \\
\text { stone block }\end{array}$ & Beton & {$[25]$} \\
\hline $\begin{array}{l}\text { Riparian } \\
\text { stability }\end{array}$ & Stable, undamaged & Less erosion & Erosion is less than $50 \%$ & $\begin{array}{c}\text { Erosion ranges } \\
\text { from } 50 \% \text { to } \\
80 \%\end{array}$ & $\begin{array}{l}\text { Erosion greater } \\
\text { than } 80 \%\end{array}$ & {$[26]$} \\
\hline Bed stability & $\begin{array}{l}\text { Stable, no obvious } \\
\text { deposition }\end{array}$ & & $\begin{array}{l}\text { Less stable, moderate } \\
\text { deposition }\end{array}$ & & $\begin{array}{l}\text { Seriously } \\
\text { degraded and } \\
\text { unstable }\end{array}$ & {$[25]$} \\
\hline $\begin{array}{c}\text { Plaque } \\
\text { fragmentation } \\
\text { index }\end{array}$ & $\leq 0.2$ & $0.2<\mathrm{N} \leq 0.4$ & $0.4<\mathrm{N} \leq 0.6$ & $0.6<\mathrm{N} \leq 0.8$ & $>0.8$ & {$[27]$} \\
\hline $\begin{array}{l}\text { Bottom } \\
\text { material }\end{array}$ & $\begin{array}{l}\text { Gravel equal to } \\
\text { greater than } 80 \%\end{array}$ & $\begin{array}{c}\text { Gravel waits at } \\
60-80 \%\end{array}$ & Gravel waits at $40 \%-60 \%$ & $\begin{array}{l}\text { Gravel waits } \\
\text { at } 20 \% \sim 40 \%\end{array}$ & $\begin{array}{c}\text { Gravel is less } \\
\text { than } 20 \%\end{array}$ & {$[26]$} \\
\hline $\begin{array}{l}\text { Riparian } \\
\text { width (m) }\end{array}$ & $90 \sim 100$ & $80 \sim 90$ & $70 \sim 80$ & $50 \sim 70$ & $<50$ & [28] \\
\hline
\end{tabular}

Table 2. Criteria for evaluating the buffer function of natural habitats in riparian zones.

\begin{tabular}{|c|c|c|c|c|c|c|}
\hline \multirow{2}{*}{ Parameters } & \multicolumn{5}{|c|}{ Evaluation Criterion } & \multirow{2}{*}{ Reference } \\
\hline & Excellent & Good & Medium & Worse & $\mathrm{Bad}$ & \\
\hline Water, $\mathrm{NH}_{3}-\mathrm{N}(\mathrm{mg} / \mathrm{L})$ & $\leq 0.015$ & $\leq 0.5$ & $\leq 1.0$ & $\leq 1.5$ & $\leq 2.0$ & $\begin{array}{c}\text { Environmental quality standards for } \\
\text { surface water of China (GB 3838-2002) }\end{array}$ \\
\hline Water, TP (mg/L) & $\leq 0.02$ & $\leq 0.1$ & $\leq 0.2$ & $\leq 0.3$ & $\leq 0.4$ & $\begin{array}{l}\text { Environmental quality standards for } \\
\text { surface water of China (GB 3838-2002) }\end{array}$ \\
\hline Water, $\mathrm{Cu}(\mathrm{mg} / \mathrm{L})$ & $\leq 0.01$ & $\leq 1.0$ & $\leq 1.0$ & $\leq 1.0$ & $\leq 1.0$ & $\begin{array}{c}\text { Environmental quality standards for } \\
\text { surface water of China (GB 3838-2002) }\end{array}$ \\
\hline Water, DO (mg/L) & $\geq 7.5$ & $5-7.5$ & $3-5$ & $2-3$ & $\leq 2$ & $\begin{array}{c}\text { Environmental quality standards for } \\
\text { surface water of China (GB 3838-2002) }\end{array}$ \\
\hline Soil, AK (mg/kg) & $>200$ & $150 \sim 200$ & $100 \sim 150$ & $50 \sim 100$ & $<50$ & $\begin{array}{l}\text { Nutrient classification standards for the } \\
\text { second national soil census (China) }\end{array}$ \\
\hline Soil, TN (g/kg) & $\geq 2.0$ & $1.5 \sim 2.0$ & $1.0 \sim 1.5$ & $0.5 \sim 1.0$ & $<0.5$ & $\begin{array}{l}\text { Nutrient classification standards for the } \\
\text { second national soil census (China) }\end{array}$ \\
\hline Soil, $\mathrm{Cu}(\mathrm{mg} / \mathrm{kg})$ & $\leq 35$ & $35 \sim 50$ & $50 \sim 100$ & $50 \sim 100$ & $100 \sim 400$ & $\begin{array}{c}\text { Soil environmental quality standards of } \\
\text { China(GB 15618-2018) }\end{array}$ \\
\hline Soil, Cr (mg/kg) & $\leq 90$ & $90 \sim 250$ & $250 \sim 300$ & $300 \sim 350$ & $350 \sim 500$ & $\begin{array}{l}\text { Soil environmental quality standards of } \\
\text { China (GB 15618-2018) }\end{array}$ \\
\hline $\mathrm{ACP}$ & $45 \sim 50$ & $40 \sim 45$ & $30 \sim 40$ & $20 \sim 30$ & $<20$ & {$[25]$} \\
\hline ALP & $\geq 60$ & $50 \sim 60$ & $40 \sim 50$ & $30 \sim 40$ & $\leq 30$ & [29] \\
\hline Urease & $\geq 1000$ & $900 \sim 1000$ & $800 \sim 900$ & $700 \sim 800$ & $\leq 700$ & [29] \\
\hline Channel curvature & $>3$ & 3 & 2 & 1 & 0 & {$[25]$} \\
\hline Topographic connectivity & $0.1 \sim 0.5$ & $0.5 \sim 0.9$ & $0.9 \sim 1.3$ & $1.3 \sim 1.8$ & $>1.8$ & [30] \\
\hline $\begin{array}{l}\text { Wetland conservation } \\
\text { ratio }(\%)\end{array}$ & $>30$ & 20 30 & $10 \sim 20$ & $5 \sim 10$ & $<5$ & [25] \\
\hline
\end{tabular}

Annotation: TP: total phosphorus. AK: available potassium. ACP: acid phosphatase. ALP: alkaline phosphatase. 
Table 3. Criteria for evaluating the service function of natural habitats in riparian zones.

\begin{tabular}{|c|c|c|c|c|c|c|}
\hline \multirow{2}{*}{ Parameters } & \multicolumn{5}{|c|}{ Evaluation Criterion } & \multirow{2}{*}{ Reference } \\
\hline & Excellent & Good & Medium & Worse & $\mathrm{Bad}$ & \\
\hline $\begin{array}{l}\text { Human beings mainly } \\
\text { affect activities }\end{array}$ & $\begin{array}{l}\text { Very little human } \\
\text { activity }\end{array}$ & $\begin{array}{l}\text { Walk or bike } \\
\text { less }\end{array}$ & $\begin{array}{l}\text { Walk or bike } \\
\text { more }\end{array}$ & $\begin{array}{l}\text { Less motor } \\
\text { vehicle }\end{array}$ & $\begin{array}{l}\text { More motor } \\
\text { vehicles }\end{array}$ & [26] \\
\hline $\begin{array}{c}\text { Abundance of recreational } \\
\text { facilities }\end{array}$ & $\geq 5$ & $3 \sim 4$ & 2 & 1 & 0 & {$[25]$} \\
\hline Corridor connectivity & Unblocked & Little obstacles & $\begin{array}{l}\text { Interrupt } \\
1 \sim 2 \text { times }\end{array}$ & $\begin{array}{l}\text { Interrupt } \\
3 \sim 5 \text { times }\end{array}$ & $\begin{array}{l}\text { Interrupt more } \\
\text { than } 5 \text { times }\end{array}$ & {$[25]$} \\
\hline Grazing conditions & Without & $\begin{array}{l}\text { On one side of } \\
\text { the less }\end{array}$ & $\begin{array}{l}\text { On one side } \\
\text { more }\end{array}$ & $\begin{array}{l}\text { Less on } \\
\text { both sides }\end{array}$ & More on both sides & {$[31]$} \\
\hline
\end{tabular}

Table 4. Criteria for evaluating the biodiversity of natural habitats in riparian zones.

\begin{tabular}{|c|c|c|c|c|c|c|}
\hline \multirow{2}{*}{ Parameters } & \multicolumn{5}{|c|}{ Evaluation Criterion } & \multirow{2}{*}{ Reference } \\
\cline { 2 - 7 } & Excellent & Good & Medium & Worse & Bad & $\leq 10$ \\
\hline Vegetation coverage activities (\%) & $\geq 80$ & $60 \sim 80$ & $40 \sim 60$ & $10 \sim 40$ & $\leq 30]$ \\
\hline Simpson index of vegetation & $0.8 \sim 1$ & $0.6 \sim 0.8$ & $0.4 \sim 0.6$ & $0.2 \sim 0.4$ & $\leq 0.2$ & {$[32]$} \\
\hline Vegetation evenness index & $\geq 0.8$ & $0.7 \sim 0.8$ & $0.6 \sim 0.7$ & $0.5 \sim 0.6$ & $\leq 0.5$ & {$[32]$} \\
\hline Microbial Shannon-Wiener index & $\geq 10$ & $9.5 \sim 10$ & $9.0 \sim 9.5$ & $8.5 \sim 9.0$ & $\leq 8.5$ & {$[33]$} \\
\hline Microbial OTUs & $\geq 2600$ & $2200 \sim 2600$ & $1900 \sim 2200$ & $1500 \sim 1900$ & $\leq 1500$ & {$[33]$} \\
\hline
\end{tabular}

Water DO: Hash multiparameter water quality analyzer. Water $\mathrm{Cu}$, soil $\mathrm{Cu}$ and soil $\mathrm{Cr}$ : atomic absorption spectrophotometer;

Soil available potassium (AK) and soil total nitrogen (TN): TRF-4A high-intelligence soil tester;

Simpson index of vegetation diversity computational formula:

$$
\mathrm{D}=1-\sum_{i=1}^{s} P_{i}^{2}
$$

Plant evenness index ( $\left.\mathrm{J}^{\prime}\right)$ computational formula:

$$
\mathrm{J}^{\prime}=\mathrm{H}^{\prime} / \ln \mathrm{S}
$$

...where $\mathrm{Pi}$ is the importance of species $\mathrm{i}, \mathrm{S}$ is the number of species in the plot, H' is the Shannon-Wiener diversity index [34, 35].

Microbial Shannon-Wiener diversity index, microbial OTUs: high throughput sequencing analysis $[36,37]$.

\section{Evaluation Method}

The comprehensive index method adopts the method of weighted sum between the index data and the weight, which is not limited to whether the index is quantified. The evaluation results are based on each indicator's different weights that change as each indicator changes, and are accurate. This method's key point is that field investigation and expert consultation should be carried out before establishing an indicator system in order to create indicator weights that align more with the research area. Therefore, the comprehensive index method is suggested to evaluate the restoration status of natural habitat in Liao River reserve's riparian zone [38, 39].

Evaluation steps of comprehensive index method:

(1) Determine the current status of each indicator;

(2) Assign each evaluation index according to evaluation criteria;

(3) Calculate the composite index:

$$
E=\sum_{i=1}^{\mathrm{n}} \lambda_{\mathrm{i}} \times W \mathrm{i}
$$

...where $\mathrm{E}$ is the comprehensive index, $\mathrm{n}$ is the number of evaluation indicators, $\lambda_{i}$ is the assigned value of each evaluation index, and $\mathrm{W}_{\mathrm{i}}$ is the weight of each evaluation index.

\section{Results and Discussion}

\section{Stabilization Function}

Stable riparian zones can provide effective habitats and food sources for plants and animals, thus enriching 
Table 5. Stability index data of natural habitat in the Liao River reserve's riparian zone.

\begin{tabular}{|c|c|c|c|c|c|c|c|}
\hline \multirow{2}{*}{$\begin{array}{l}\text { Sampling } \\
\text { point }\end{array}$} & \multirow{2}{*}{ Slope types } & \multirow{2}{*}{ Riparian stability } & \multirow{2}{*}{ Bed stability } & \multirow{2}{*}{$\begin{array}{c}\text { Plaque } \\
\text { fragmentation } \\
\text { index }\end{array}$} & \multirow{2}{*}{ Bottom material } & \multicolumn{2}{|c|}{ Riparian width } \\
\hline & & & & & & left & right \\
\hline $\mathrm{Z1}$ & Natural prototype & Relatively stable & stable & 0.2 & $\mathrm{Bad}$ & 70 & 190 \\
\hline $\mathrm{Z} 2$ & Natural prototype & Relatively stable & stable & 0.2 & $\mathrm{Bad}$ & 40 & 150 \\
\hline $\mathrm{Z3}$ & Gabion revetment & Relatively stable & Secondary sludge & 0.3 & $\begin{array}{l}\text { Big Stone, } \\
\text { excellent }\end{array}$ & 80 & 1000 \\
\hline $\mathrm{Z} 4$ & $\begin{array}{l}\text { Near natural } \\
\text { prototype }\end{array}$ & Medium & Stable & 0.3 & Big Stone, medium & 123 & 50 \\
\hline $\mathrm{Z} 5$ & $\begin{array}{l}\text { Near natural } \\
\text { prototype }\end{array}$ & Worse & $\begin{array}{l}\text { Silt seriously, } \\
\text { unstable }\end{array}$ & 0.5 & silver sand, bad & 400 & 430 \\
\hline Z6 & Rockfill, Worse & Relatively stable & Stable, many plants & 0.5 & Big Stone, medium & 120 & 110 \\
\hline $\mathrm{Z7}$ & $\begin{array}{c}\text { Near natural } \\
\text { prototype, Scouring } \\
\text { serious }\end{array}$ & Relatively stable & $\begin{array}{l}\text { Silt more, Herbs } \\
\text { less, medium }\end{array}$ & 0.5 & Sludge, sand, bad & 150 & 160 \\
\hline Z8 & $\begin{array}{l}\text { Natural prototype, } \\
\text { No flushing }\end{array}$ & Stable & Excellent & 0.2 & $\begin{array}{l}\text { Big Stone, } \\
\text { excellent }\end{array}$ & 140 & 150 \\
\hline Z9 & $\begin{array}{l}\text { Near natural } \\
\text { prototype, flushing }\end{array}$ & $\begin{array}{c}\text { Serious } \\
\text { degradation, bad }\end{array}$ & $\begin{array}{c}\text { Serious degradation, } \\
\text { bad }\end{array}$ & 0.5 & $\begin{array}{l}\text { Little big stone, } \\
\text { main sand, Worse }\end{array}$ & 105 & 130 \\
\hline $\mathrm{Z} 10$ & Natural prototype & $\begin{array}{l}\text { Left bank light, } \\
\text { right bank without } \\
\text { erosion }\end{array}$ & $\begin{array}{c}\text { Serious degradation, } \\
\text { bad }\end{array}$ & 0.5 & $\begin{array}{l}\text { Main big stone, } \\
\text { silver sand, } \\
\text { medium }\end{array}$ & 100 & 80 \\
\hline Z11 & $\begin{array}{l}\text { Near natural } \\
\text { prototype }\end{array}$ & $\begin{array}{c}\text { Extreme } \\
\text { degradation }\end{array}$ & $\begin{array}{c}\text { Serious degradation, } \\
\text { unstable }\end{array}$ & 0.7 & $\begin{array}{l}\text { Big Stone, sludge, } \\
\text { Middle for sand, } \\
\text { poor }\end{array}$ & 500 & 800 \\
\hline $\mathrm{Z} 12$ & $\begin{array}{l}\text { Near natural } \\
\text { prototype }\end{array}$ & $\begin{array}{l}\text { Upper stability, } \\
\text { interception } \\
\text { degradation }\end{array}$ & $\begin{array}{l}\text { No shoals in the } \\
\text { upstream and no } \\
\text { serious in the } \\
\text { downstream }\end{array}$ & 0.2 & $\begin{array}{c}\text { Sand, Little stone, } \\
\text { bad }\end{array}$ & 120 & 100 \\
\hline $\mathrm{Z} 13$ & $\begin{array}{l}\text { Near natural } \\
\text { prototype }\end{array}$ & Worse & $\begin{array}{c}\text { Secondary sludge, } \\
\text { unstable }\end{array}$ & 0.5 & $\begin{array}{c}\text { Sand, no big stone, } \\
\text { bad }\end{array}$ & 500 & 900 \\
\hline $\mathrm{Z} 14$ & rockfill & $\begin{array}{c}\text { Right slope } \\
\text { protection, stable }\end{array}$ & Instability, Silt more & 0.7 & $\begin{array}{c}\text { Less big stone, } \\
\text { more sandy, mud, } \\
\text { bad }\end{array}$ & 350 & 300 \\
\hline $\mathrm{Z} 15$ & Natural prototype & Unstable, bad & Silt more, bad & 0.7 & $\begin{array}{c}\text { Silver sand, sludge, } \\
\text { bad }\end{array}$ & $\geq 1000$ & 300 \\
\hline $\mathrm{Z} 16$ & $\begin{array}{l}\text { Near natural } \\
\text { prototype }\end{array}$ & $\begin{array}{l}\text { Part of the slope } \\
\text { protection, Serious } \\
\text { erosion, instability }\end{array}$ & More shallow, bad & 0.5 & $\begin{array}{l}\text { Big Stone, silver } \\
\text { sand, bad }\end{array}$ & 300 & 220 \\
\hline $\mathrm{Z} 17$ & $\begin{array}{l}\text { Near natural p } \\
\text { rototype (rockfill) }\end{array}$ & $\begin{array}{l}\text { Less than } 50 \% \\
\text { scour, Relatively } \\
\text { stable }\end{array}$ & $\begin{array}{c}\text { Secondary } \\
\text { degeneration, } \\
\text { shallow, medium }\end{array}$ & 0.5 & Silver sand, bad & 232.1 & 137.8 \\
\hline Z18 & rockfill & Instability & $\begin{array}{l}\text { Secondary sludge, } \\
\text { Relatively stable }\end{array}$ & 0.5 & Sludge, bad & 370 & 50 \\
\hline Z19 & Natural prototype & Medium & Secondary sludge & 0.5 & Silt more, bad & 210 & 30 \\
\hline $\mathrm{Z} 20$ & Natural prototype & Good & Secondary sludge & 0.3 & Secondary sludge & 40 & 30 \\
\hline $\mathrm{Z} 21$ & Natural prototype & Stable, excellent & Stable & 0.2 & $\begin{array}{c}\text { No silt, Big stone, } \\
\text { excellent }\end{array}$ & 500 & 550 \\
\hline $\mathrm{Z} 22$ & Natural prototype & Stable & Stable & 0.2 & $\begin{array}{c}\text { Sludge, Big Stone, } \\
\text { bad }\end{array}$ & 10 & 30 \\
\hline Z23 & Natural prototype & Stable & Stable & 0.2 & Sludge, No stone & $>1000$ & $>1000$ \\
\hline
\end{tabular}




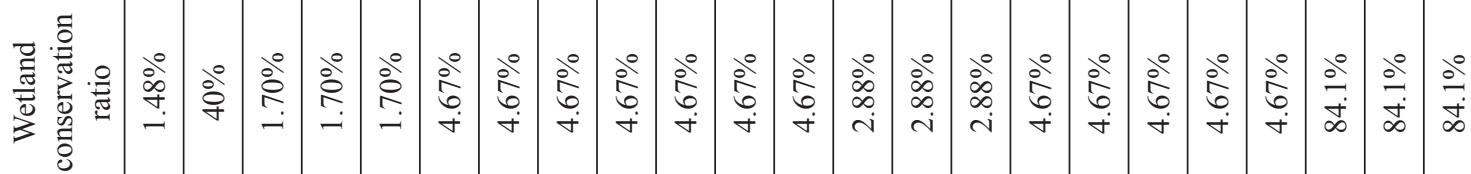

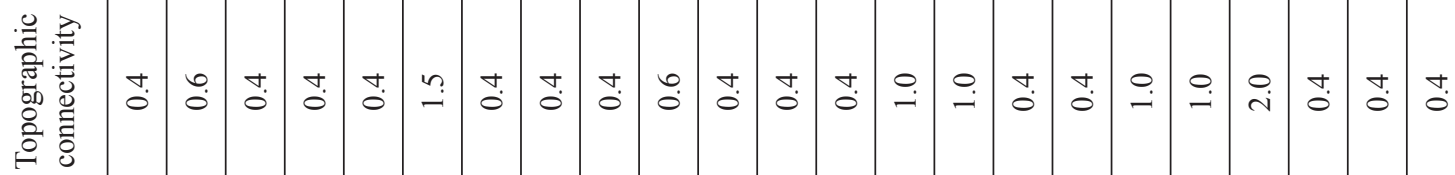

恶害

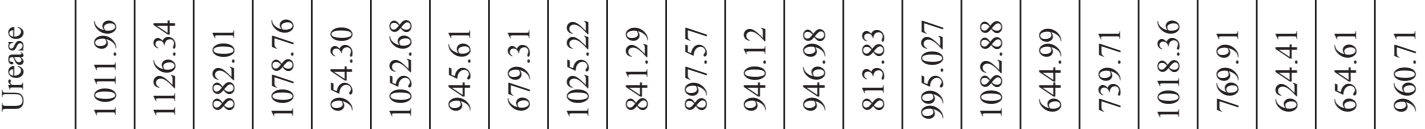

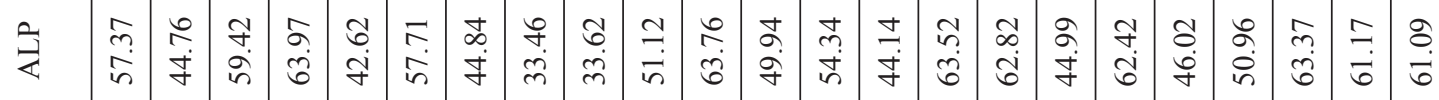

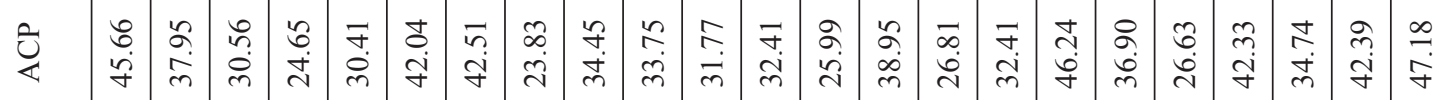

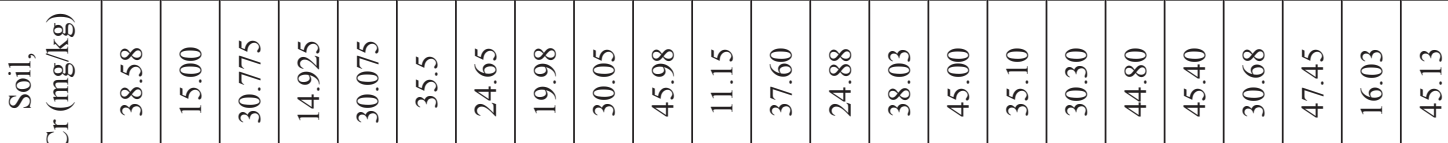

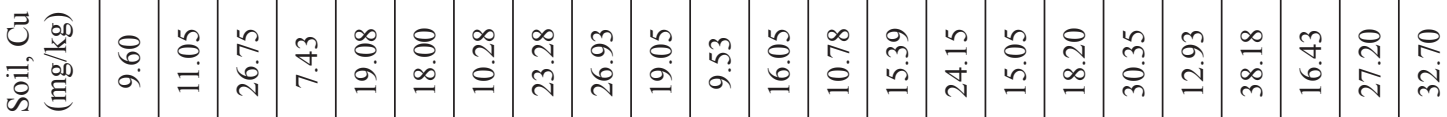

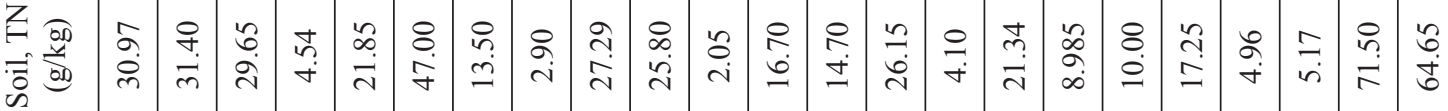

य

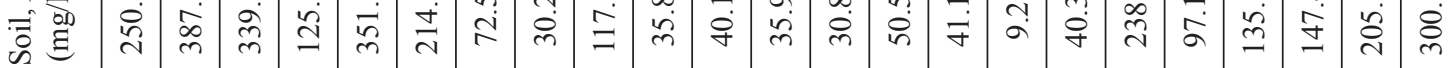

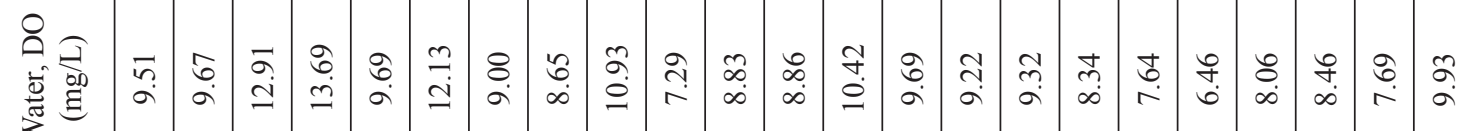

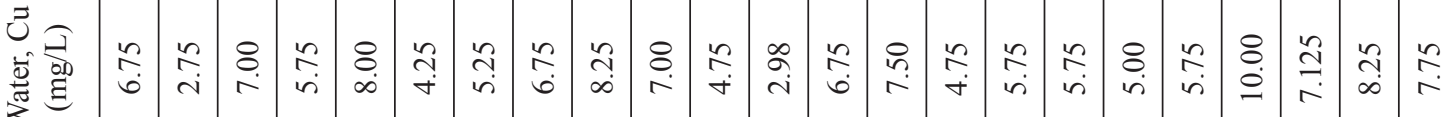

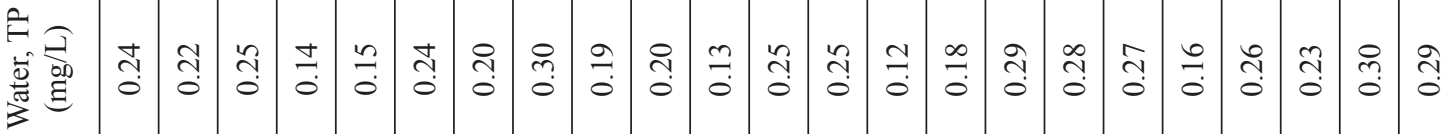

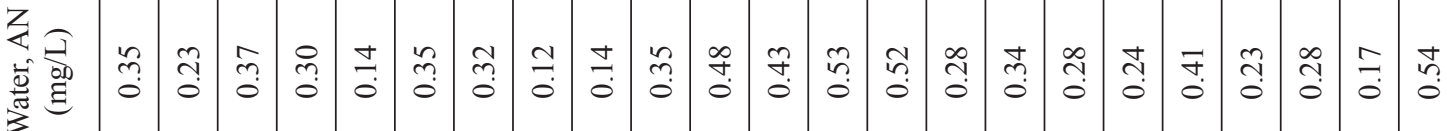

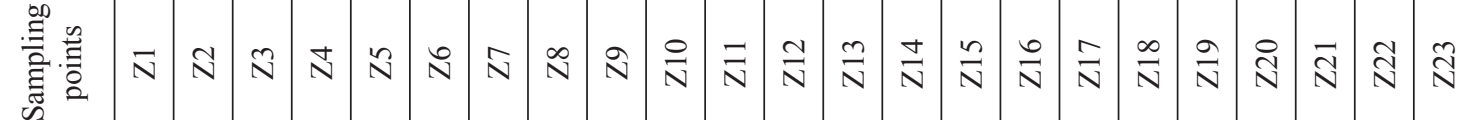


biodiversity. The stability function includes two aspects: environmental stability and species stability. The stability function of the evaluation index for natural habitat restoration in the Liao River reserve's riparian zone includes six indicators, and the index data are shown in Table 5.

Based on a field investigation of 23 sampling points in the Liao River reserve, it can be concluded that 10 types of bank slopes in the riparian zone of this reserve are natural prototypes, and 9 types are near-natural prototypes. The Liao River Basin has 5 riparian zones in stable and unstable states, accounting for $21.7 \%$ of the whole basin. Artificial revetment measures are incomplete, resulting in serious erosion of some bank slopes and affecting riparian stability. Among the sampling points, $30.4 \%$ of riverbed stability was in a stable state, and most of the riverbeds had varying degrees of deposition or degradation. Riverbed stability was closely related to river biodiversity. The stabilization function of riparian natural habitat in the Liao River's reserve needs improvement, and riparian zone stability can be improved by increasing slope protection and reducing human activities to provide more stable habitats for animals and plants, which can enhance the function of riparian natural habitat.

\section{Buffer Function}

When the riparian zone is disturbed by human activities or destroyed by natural disasters, this zone's self-regulation ability reduces destruction and interference. The buffer function of the evaluation index for natural habitat restoration in the Liao River reserve's riparian zone includes 14 indicators, whose data are shown in Table 6.

River water quality is an important index that affects the function of rivers and has a direct impact on plants, animals and microorganisms in rivers. The water quality of the Liao River's main stream has been specially treated during the $12^{\text {th }}$ Five-Year Plan, and it has exceeded grade $\mathrm{V}$ in the Environmental Quality Standard for Surface Water (GB 3838-2002). In this study, the maximum value of ammonia nitrogen content in the water is $0.54 \mathrm{mg} / \mathrm{L}$ and the minimum value is $0.12 \mathrm{mg} / \mathrm{L}$, both exceeding grade IV. The maximum value of total phosphorus content in the water body is $0.3 \mathrm{mg} / \mathrm{L}$, and the minimum value is $0.12 \mathrm{mg} / \mathrm{L}$, which all meet the quality standards of class IV and above. The content of heavy metal $\mathrm{Cu}$ in the water reaches the quality standard of class I. The maximum value of DO content in the water is $13.69 \mathrm{mg} / \mathrm{L}$, and the minimum value is $7.29 \mathrm{mg} / \mathrm{L}$, both of which have reached the quality standard of class II. According to the Soil Environmental Quality Standard (GB 15618-1995), the heavy metal content in the Liao River reserve's riparian zone did not exceed the standard. According to the nutrient grading standard of China's second national soil survey, the soil TN content in the Liao River reserve's riparian zone reached the level of grade II and above, AK content in the riparian zone of some sampling sites was low, and AK content in the Hongmiaozi sampling site was $9.285 \mathrm{mg} / \mathrm{kg}$, which was very low, so the soil at the sampling site could not meet the needs of crop growth. In the Liao River reserve, the sampling site with the highest wetland retention rate is the Red Beach sampling site, which is a wetland ecotourism scenic spot and its functions are to protect biodiversity, improve water quality and regulate climate.

\section{Service Function}

When the riparian zone is disturbed by human activities or destroyed by natural disasters, this zone's self-regulation ability will reduce destruction and interference. The buffer function of the evaluation index for natural habitat restoration in the Liao River reserve's riparian zone includes 14 indicators, whose data are shown in Table 7.

Based on the field investigation of service function, it can be concluded that recent human activities in the Liao River's reserve have seriously disturbed this area, and it has relatively few recreational facilities. Human activities such as dredging and fishing are frequent in some areas, which have a negative impact on the restoration of natural habitats in the riparian zone. In addition, in recent years, the grazing situation in the Liao River has greatly increased, resulting in poor restoration of vegetation diversity and soil microbial diversity in riparian zones, thus impeding the sustainable restoration of natural habitats in the Liao River reserve's riparian zone.

\section{Biodiversity}

The riparian zone's biodiversity can directly reflect the degree of its natural recovery and has the functions of water conservation and purification as well as disaster prevention and control through filtration, infiltration, absorption and interception of the riparian vegetation zone. The riparian zone's biodiversity evaluation can provide some references for its ecosystem and river health evaluations, and also can provide some basis for its ecological construction and restoration [40, 41]. The biodiversity function of the evaluation index established in this paper includes 5 indicators: vegetation Simpson diversity (Fig 3), vegetation uniformity (Fig. 4), vegetation coverage (Fig. 5), microbial Shannon diversity (Fig. 6) and microbial OTUs (Fig. 7).

Simpson diversity index can reflect the degree of dominance of plant species in plant communities. According to field survey data, Simpson diversity index of the Liao River's 23 sampling points is between 0.153 and 0.781 , with an average value of 0.558 . Among them, Simpson diversity index's highest sampling point appeared at Shuan'an Bridge with an index of 0.781, indicating that it had a large dominance of plants. Simpson diversity index's lowest sampling point was 
Table 7. Service index data of natural habitat in the Liao River reserve's riparian zone.

\begin{tabular}{|c|c|c|c|c|}
\hline $\begin{array}{l}\text { Sampling } \\
\text { points }\end{array}$ & $\begin{array}{c}\text { Human beings mainly affect } \\
\text { activities }\end{array}$ & $\begin{array}{c}\text { Abundance of recreational } \\
\text { facilities }\end{array}$ & $\begin{array}{l}\text { Corridor } \\
\text { connectivity }\end{array}$ & Grazing conditions \\
\hline $\mathrm{Z1}$ & Little human activity & Landscape units & Little obstacles & None \\
\hline $\mathrm{Z2}$ & Motor vehicles & Angling & Unblocked & None \\
\hline $\mathrm{Z3}$ & Human, Motor vehicles & None & Interrupt one & More on right bank \\
\hline $\mathrm{Z} 4$ & $\begin{array}{c}\text { Less motor vehicles, Less humans, } \\
\text { Catching fish } \\
\end{array}$ & None & Unblocked & Less \\
\hline $\mathrm{Z} 5$ & Grazing & None & Little obstacles & Less \\
\hline Z6 & Less motor vehicles, Less angling & None & Little obstacles & None \\
\hline $\mathrm{Z7}$ & $\begin{array}{c}\text { Less motor vehicles, Angling, Swim- } \\
\text { ming }\end{array}$ & None & Unblocked & More \\
\hline $\mathrm{Z} 8$ & Angling & None & Unblocked & More \\
\hline Z9 & Angling, Swimming & Landscape units & Little obstacles & Less \\
\hline $\mathrm{Z10}$ & Angling, Digging sand & Landscape units, Rubber dam & Little obstacles & Medium \\
\hline Z11 & Angling, Digging sand & None & Unblocked & More \\
\hline $\mathrm{Z} 12$ & Catching fish & Landscape units, Rubber dam & Unblocked & None \\
\hline $\mathrm{Z} 13$ & Catching fish & Floating bridge & Unblocked & Common \\
\hline Z14 & None & None & Interrupt two & More on one side \\
\hline Z15 & None & None & Little obstacles & More \\
\hline Z16 & None & Landscape units & Unblocked & None \\
\hline $\mathrm{Z17}$ & Less motor vehicles & None & Unblocked & Present \\
\hline Z18 & Floating bridge, More motor vehicles & None & Little obstacles & None \\
\hline Z19 & Less motor vehicles & None & Little obstacles & None \\
\hline $\mathrm{Z} 20$ & Less motor vehicles & Landscape units & Interrupt two & None \\
\hline $\mathrm{Z} 21$ & Less humans, Less motor vehicles & Landscape units & Unblocked & None \\
\hline $\mathrm{Z} 22$ & Less motor vehicles & None & Unblocked & None \\
\hline $\mathrm{Z} 23$ & Little human activity & Excellent & Unblocked & None \\
\hline
\end{tabular}

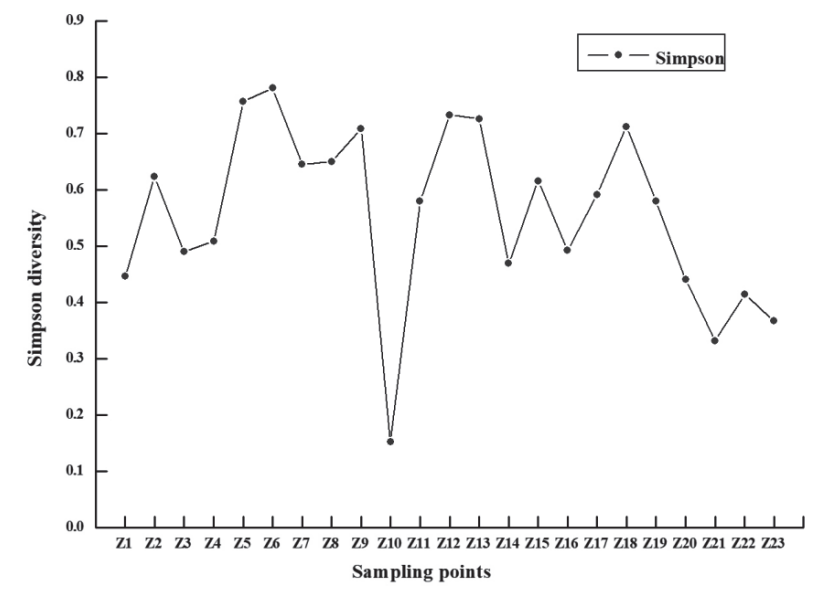

Fig. 3. Simpson diversity index of riparian vegetation in the Liao River's main stream.

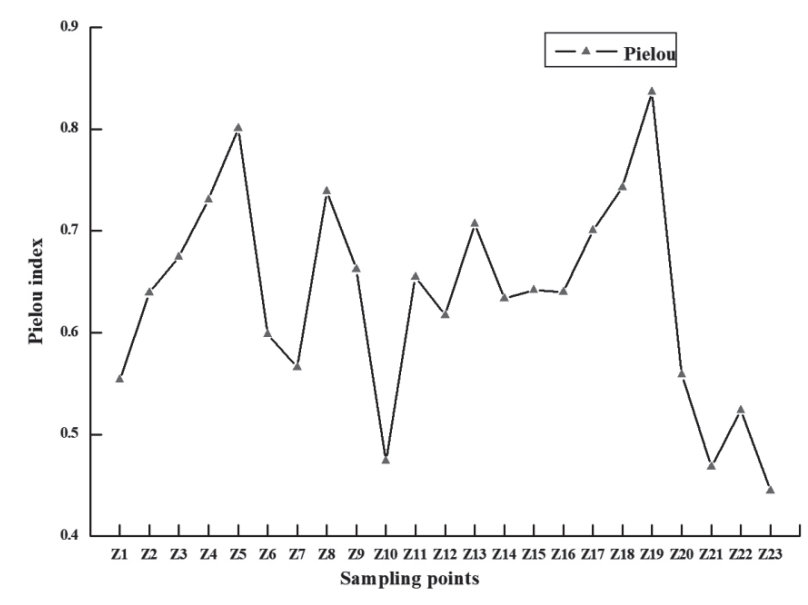

Fig. 4. Pielou evenness index of the Liao River's main stream's riparian zone. 


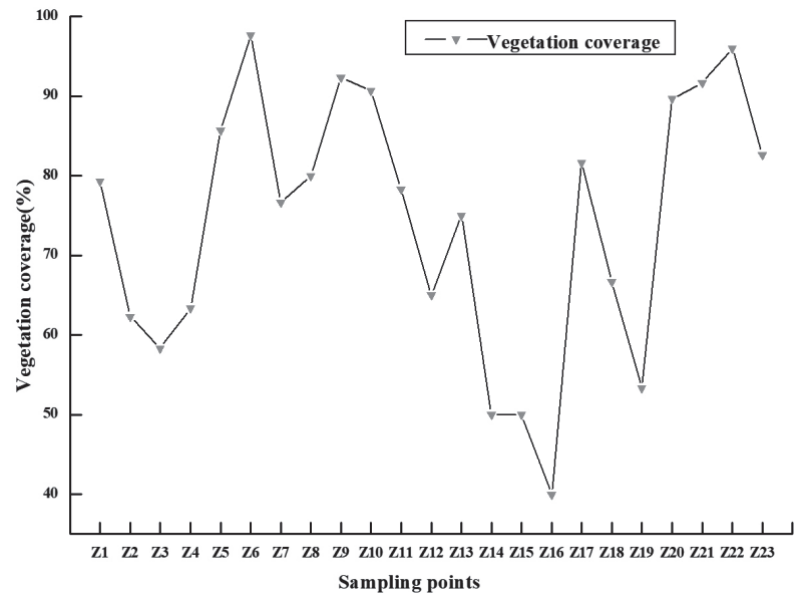

Fig. 5. Vegetation coverage of the Liao River's main stream's riparian zone.

found at Mahushan Bridge, and its diversity index was 0.153 .

Pielou evenness index reflects the uniformity of distribution of the number of each individual species across an area, as well as direct evidence of responses of plant species and growth conditions [35]. According to an investigation of the Liao River reserve's riparian zone vegetation, it can be concluded: the Pielou evenness index of the Liao River's 23 sample areas was between $0.445 \sim 0.837$, and the average Pielou evenness index was 0.635. In the Liao River's main stream, the highest point of plant evenness index in its riparian zone was 0.837. It appeared in Lengdong Bridge, indicating that the species distribution degree at this sampling point was good, and its plant growth condition was higher than that of other sampling points. The lowest point was 0.445 , which appeared at the Red Beach's estuary, indicating that this sampling point's

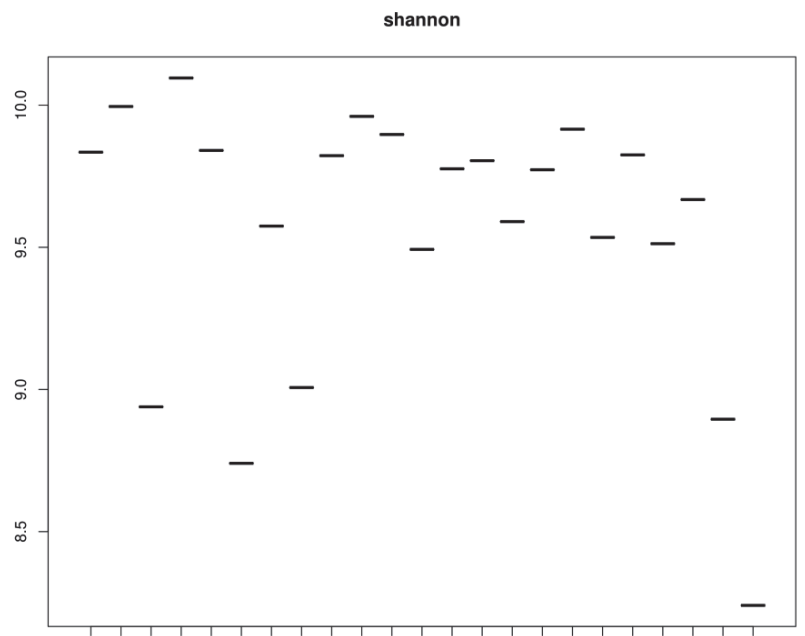

N

Fig. 6. Microbial Shannon diversity in the Liao River's main stream. plant growth condition was poor compared with other sampling points.

According to research on the Liao River's riparian zone vegetation coverage situation, it can be concluded that the average vegetation coverage of the Liao River's 23 sampling points was $74.19 \%$, and as the vegetation coverage apogee, the Shuang'an Bridge sampling point's vegetation coverage reached $97.67 \%$. Shuang'an Bridge has artificial vegetation revetment, less human activities, and no grazing. Therefore, this sampling point's vegetation recovery is good, and its vegetation coverage rate is higher than other sampling points. The lowest point occurred at Hongmiaozi, with the lowest vegetation coverage at only $40 \%$. Poplar and willow species were abundant at the Hongmiaozi sampling site's riparian zone, while there were relatively few herbs, so they had a relatively low level of vegetation coverage.

The Shannon-Weiner diversity index can reflect the complexity of microbial community structure and function. Based on high-throughput sequencing analysis of soil microorganisms, it can be concluded that the mean Shannon diversity index in the Liao River reserve's riparian zone is 9.55, and the Shannon diversity index of the Xiguchengzi sampling site is the highest (10.095), indicating that this sampling site's microbial diversity is significantly higher than that of other sampling sites. The Shannon diversity index of the Red Beach estuary was 8.24, which was significantly lower than other sampling points, indicating that this sampling site's microbial species and diversity were few and low.

According to the distribution map of soil microbial quantity in the riparian zone of the Liao River's main stream, it can be concluded that Xiguchengzi is its area with the largest number of bacteria, and its total OTU quantity is 2682, indicating that the microbial diversity of this sampling site is higher than that of other sampling sites. The point with the lowest number

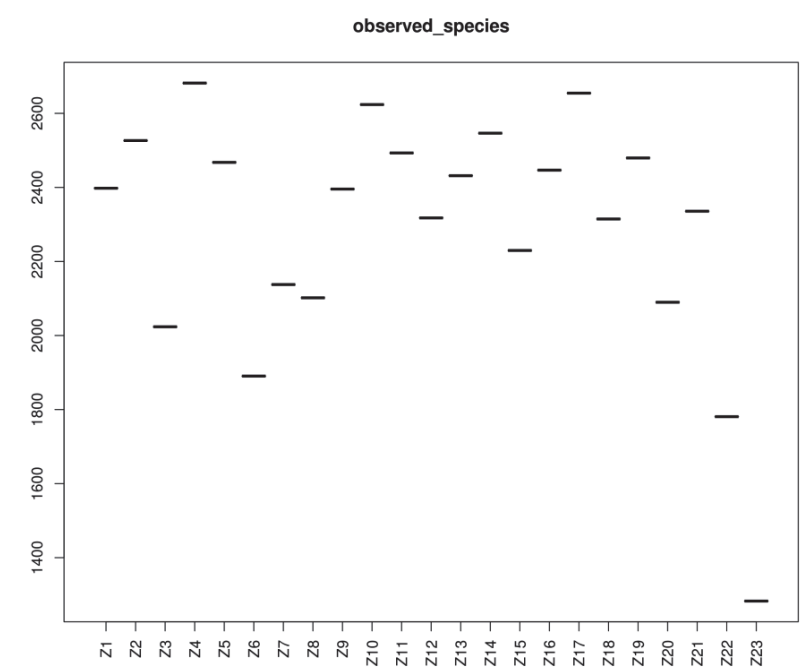

Fig. 7. Microbial quantity in the Liao River's main stream. 
of bacteria is located at the Red Beach's estuary, where there are 1283 OTUs. The number of this sampling site's microbial bacteria is slightly lower than that in other sampling sites.

Based on Fig. 5 and Fig. 6, it can be concluded that: in the Liao River's riparian zone, the soil samples that are nearer to the sea have a lower number of microorganisms and microbial diversity. When analyzing the possible reasons for this, there are basically the following three aspects: (1) The influence of salinity: Due to the high salinity of sea water, coastal areas have high salinity. Some of this area's microbes are insufficiently resistant to salinity and cannot survive in this area, so its microbial diversity and abundance is generally low. (2) Influenced by temperature: The temperature near the seawater area is low compared with other sampling points. Low temperature will inhibit the activity of some microorganisms, which may reduce their survival rate. (3) Affected by vegetation: Zhaoquan River and Red Beach's plant diversity are lower than that of other sampling points. In addition, plant litter quantity decreases with a reduction in the number of plants, and decomposing plant litter reduces microbial quantity. At the same time, a synergistic effect exists between microorganisms and plants. In this case, the rhizosphere of plants can provide nutrients

Table 8. Evaluation index weight of natural habitat restoration in the Liao River's riparian zone.

\begin{tabular}{|c|c|c|c|}
\hline Habitat features & Weight & Indexes & Weight \\
\hline \multirow{6}{*}{ Firm power energy } & \multirow{6}{*}{0.3854} & Bank slope type & 0.2298 \\
\hline & & Riparian stability & 0.1205 \\
\hline & & Bed stability & 0.2298 \\
\hline & & Habitat fragmentation & 0.1205 \\
\hline & & Bottom material & 0.0696 \\
\hline & & Riparian width & 0.2298 \\
\hline \multirow{14}{*}{ Buffer function } & \multirow{14}{*}{0.3854} & Water, AN & 0.0542 \\
\hline & & Water, TP & 0.0939 \\
\hline & & Water, $\mathrm{Cu}$ & 0.0312 \\
\hline & & Water, DO & 0.0939 \\
\hline & & Soil, AK & 0.0939 \\
\hline & & Soil, TN & 0.0939 \\
\hline & & Soil, $\mathrm{Cu}$ & 0.0312 \\
\hline & & Soil, $\mathrm{Cr}$ & 0.0312 \\
\hline & & $\mathrm{ACP}$ & 0.0312 \\
\hline & & ALP & 0.0312 \\
\hline & & Urease & 0.0542 \\
\hline & & Channel curvature & 0.0542 \\
\hline & & Topographic connectivity & 0.1528 \\
\hline & & Wetland conservation ratio & 0.1528 \\
\hline \multirow{4}{*}{ Service function } & \multirow{4}{*}{0.0871} & Human beings mainly affect activities & 0.3333 \\
\hline & & Abundance of recreational facilities & 0.1667 \\
\hline & & Corridor connectivity & 0.3333 \\
\hline & & Grazing conditions & 0.1667 \\
\hline \multirow{5}{*}{ Biodiversity } & \multirow{5}{*}{0.1422} & Vegetation coverage activities & 0.4527 \\
\hline & & Simpson index of vegetation & 0.1775 \\
\hline & & Vegetation evenness index & 0.1775 \\
\hline & & Microbial Shannon-Wiener index & 0.0962 \\
\hline & & Microbial OTUs & 0.0962 \\
\hline
\end{tabular}


Table 9. Comprehensive index method's grading evaluation criteria.

\begin{tabular}{|c|c|c|}
\hline \multicolumn{1}{|c|}{ Riparian condition } & Estimation scale & Composite index score \\
\hline $\begin{array}{c}\text { The natural habitat in the riparian zone is in a state of natural restoration and less } \\
\text { disturbed }\end{array}$ & Excellent & $\geq 16$ \\
\hline $\begin{array}{c}\text { The natural habitat in the riparian zone is in a state of near natural restoration and is } \\
\text { greatly disturbed }\end{array}$ & Well & $15 \sim 16$ \\
\hline The restoration of natural habitat in the riparian zone is seriously disturbed & General & $14 \sim 15$ \\
\hline The restoration of natural habitat in the riparian zone is strongly disturbed & Worse & $13 \sim 14$ \\
\hline Degradation of natural habitats in riparian zones & Very bad & $\leq 13$ \\
\hline
\end{tabular}

for microorganisms, which can help them develop and reproduce. Therefore, compared with other sampling sites, the number of microorganisms at Zhaoquan River and Red Beach is small.

\section{Evaluation Index Weight of Natural Habitat}

Restoration in The Liao River's Riparian Zone

In the comprehensive evaluation of riparian zone, different evaluation indexes have different effects on the restoration of the natural habitat in this zone. In order to reflect the status and importance of different indicators in the evaluation index, it is necessary to assign different weight coefficients to them. Different weights for each index lead to different evaluation results. Therefore, it is very significant to reasonably determine the index weight for obtaining accurate evaluation results. At present, weight is mostly determined based on the empirical judgment method of expert consultation. In order to improve the scientificity and objectivity of the evaluation results, this paper adopts the more mature analytic hierarchy process (AHP) to calculate index weight. According to the calculation, the evaluation index weight of natural habitat restoration in the Liao River reserve's riparian zone is shown in Table 8.

\section{Grading Criteria for The Comprehensive Index Method}

According to the status of the natural habitat restoration evaluation of the Liao River's main stream ribarian belt in the its protection area, comprehensive index method was used to formulate appropriate grading evaluation criteria, as shown in Table 9.

\section{Analysis of Natural Habitat Restoration in The Liao River's Riparian Zone}

The comprehensive index method was used to evaluate the restoration status of natural habitat in the Liao River reserve's riparian zone with 23 sampling points. The evaluation results are shown in Table 10 .

Among the Liao River's main stream's 23 sampling points, there were 5 banks with excellent natural habitat recovery, accounting for $21.74 \%$ of all the sampling points. These 5 sampling points were less disturbed by human activities and no obvious erosion was observed on the bank slope. Shuguang Highway Rubber Dam on both sides of the gabion slope protection had aquatic vegetation and a smooth channel. The bank had a landscape platform, and retained its wetlands, which improved the function of its riparian habitat. In the sampling site of Zhu'er Mountain, grazing occurred in the evening, but no grazing was found in the other four sampling sites. The banks of this sampling site contained large willows and other plants, which had a positive effect on the habitat restoration of the riparian zone. Therefore, the natural habitat in the riparian zone of these five sampling sites was in a state of natural recovery, this zone was relatively stable, the landscape was suitable, the habitat structure was complete, and the riparian zone had a strong function.

The restoration status of natural habitat in the riparian zone of four sampling sites in the Liao River reserve was in good condition, accounting for $17.39 \%$ of all sampling sites. In the four sampling points with good natural habitat restoration, the river and riparian zone had different degrees of degradation, the bank slope had some stone cage slope protection, had relatively more human activities, and the impact on the riparian habitat was small. Therefore, the natural habitat in the riparian zone of these four sampling points was in a state of near natural restoration and disturbed by human activities while during the restoration process. The riparian zone was basically stable, the landscape was basically suitable, the habitat was slightly damaged, and the riparian zone had strong functions.

The Liao River's riparian zone has six sampling points whose natural habitat was undergoing general restoration, which accounted for $26.09 \%$ of all sampling points. These six sampling points on both sides of the bank had serious erosion and less side slope protection, and the Houshijiapu sampling point had invasive plant species, as well as a lot of pesticide bottles, while farming on both side of the riparian zone's bank affects its natural habitat restoration. The restoration of natural habitat in the riparian zone of these six sampling sites was seriously disturbed. During the restoration process, more human activities disturbed the riparian zone. Its structure was not stable, the landscape was not good, the habitat was destroyed, and its habitat could maintain basic functions. 
Table 10. Evaluation results of natural habitat restoration in the Liao River reserve's riparian zone.

\begin{tabular}{|c|c|c|c|}
\hline Sampling point number & Name of sampling point & Evaluation score & Assessment level \\
\hline $\mathrm{Z} 1$ & Fudedian & 16.13 & Excellent \\
\hline $\mathrm{Z} 2$ & Liaoshantou & 16.87 & Excellent \\
\hline $\mathrm{Z3}$ & Longwangmiao & 13.31 & Worse \\
\hline $\mathrm{Z} 4$ & Xiguchengzi & 15.31 & Well \\
\hline $\mathrm{Z} 5$ & Houshijipu & 14.35 & General \\
\hline Z6 & Shuang'an Bridge & 14.61 & General \\
\hline $\mathrm{Z7}$ & Fanhekou & 13.70 & Worse \\
\hline $\mathrm{Z} 8$ & Zhu'er Mountain & 16.04 & Excellent \\
\hline Z9 & Shifosi Reservoir & 15.00 & Well \\
\hline $\mathrm{Z10}$ & Mahushan Bridge & 13.71 & Worse \\
\hline $\mathrm{Z} 11$ & Juliuhe & 13.16 & Worse \\
\hline $\mathrm{Z} 12$ & Yubaotai & 15.85 & Well \\
\hline $\mathrm{Z13}$ & Zaojiaoshu & 15.43 & Well \\
\hline Z14 & Laodafang & 12.55 & Very bad \\
\hline $\mathrm{Z} 15$ & Manduhu & 12.93 & Very bad \\
\hline Z16 & Hongmiaozi & 14.16 & General \\
\hline $\mathrm{Z} 17$ & Dazhang Bridge & 14.72 & General \\
\hline Z18 & Sandaogou & 12.82 & Very bad \\
\hline Z19 & Lengdong Bridge & 12.97 & Very bad \\
\hline $\mathrm{Z} 20$ & Linfeng Bridge & 14.77 & General \\
\hline $\mathrm{Z} 21$ & Shuguang Highway Rubber Dam & 16.88 & Excellent \\
\hline $\mathrm{Z} 22$ & Zhaoquan River & 14.92 & General \\
\hline Z23 & Red Beach & 16.49 & Excellent \\
\hline
\end{tabular}

In the Liao River's main stream, four of the natural habitats in the riparian zone were in a poor recovery state, accounting for $17.39 \%$ of all sampling sites. Among them, Longwangmiao and Fanhekou sampling sites had a lot of grazing conditions, and this grazing had a negative impact on the riparian plant and soil environment. Moreover, these four sampling sites' riparian zones were relatively unstable, with serious erosion degradation, and human activities had mostly disturbed these riparian zones. Therefore, the natural habitat in the riparian zone of these four sampling points was strongly disturbed, which had a serious impact on the restoration process of the riparian zone habitat. The riparian zone structure was not stable, the habitat was severely damaged, and the functions of the natural habitat in the riparian zone were poor.

Among the 23 sampling points, there were 4 banks with a poor natural habitat restoration status, accounting for $17.39 \%$ of all sampling points. The riverbed degradation was serious in the Laodafang and Manduhu sampling sites, and the bank slope desertification was serious at the Laodafang sampling site. Moreover, many grazing conditions were found in the sampling sites, and this grazing seriously interfered with vegetation restoration in the riparian zone, thus damaging the sampling sites' soil properties and affecting various functions of the riparian zone habitat. The bank slope of Manduhu sampling site was seriously eroded and there was a lot of silt, so the functions of riparian habitat were unstable. On the left bank of the sampling site of Sandao Bridge, there was a stone field, the riparian zone was close to the road, and a pontoon bridge was built above the river. Many vehicles pass through, and nearby human activities were very frequent, so the sampling site's natural habitat restoration was seriously disturbed. At the sampling point of Lengdong Bridge, motor vehicles passed through the bridge, and oil field exploitation was conducted in the vicinity of both banks. The oil field exploitation site was close to the river, and there was no slope protection in the riparian zone. Therefore, the natural habitat in the riparian zone of the four sampling sites was degraded, the habitat structure was greatly changed, and the functions of the natural habitat in the riparian zone were very poor. 
Analysis of the Changing Trend of Natural Habitat Restoration in the Riparian Zone Compared with the Past

The comprehensive index was used to evaluate the Liao River's natural habitat restoration situation and to evaluate its historical data. The evaluation results (Table 11) show that in 2012, the Liao River's riparian zone's natural habitat had six sampling points in a poor state, respectively after Xiguchengzi, Houshijipu, Zhu'er Mountain, Yubaotai, Zaojiaoshu and the Shuguang Highway Rubber Dam. The natural habitats in the riparian zones of the other 17 sampling points were in poor condition. In 2012, the vegetation coverage of the Liao River's main stream's riparian zone in its reserve was relatively low. Although there was no grazing, the type of bank slope, the degree of bank erosion and other indicators were relatively low, which resulted in an overall low evaluation of historical data, and the Liao River reserve's riparian zone's natural habitat was in a worse and very bad state.
Based on a comparative analysis of the Liao River's main stream's 2019 and 2012 evaluation results, it was found that its reserve's riparian zone's natural habitat was in an overall restoration state. The natural habitat conditions were improved in $82.61 \%$ of the riparian zone. Three of the sampling points for the riparian zone's natural habitat conditions improved from very bad to excellent, and the natural habitat conditions at 2 sampling points improved from worse to excellent. Compared with historical data, these 5 sampling points were all in a state of natural recovery, and their vegetation coverage and plant diversity have greatly improved. Moreover, these sampling points have been less disturbed by human activities, their slope erosion is light, their riparian zone is relatively stable, their habitat structure is complete, and their ecological functions are strong. One sampling point's riparian zone's natural habitat changed from very bad to good, and 3 sampling points' natural habitat improved from worse to good. At present, the natural habitat of the riparian zone's four sampling points is in a state of near-natural recovery,

Table 11. Evaluation results of historical data of the Liao River reserve's riparian zone's natural habitat.

\begin{tabular}{|c|c|c|c|}
\hline Sampling point number & Name of sampling point & Evaluation score & Assessment level \\
\hline $\mathrm{Z1}$ & Fudedian & 12.81 & Very bad \\
\hline $\mathrm{Z} 2$ & Liao Shantou & 12.48 & Very bad \\
\hline $\mathrm{Z} 3$ & Longwangmiao & 12.65 & Very bad \\
\hline Z4 & Xiguchengzi & 13.74 & Worse \\
\hline $\mathrm{Z5}$ & Houshijipu & 13.43 & Worse \\
\hline Z6 & Shuangan Bridge & 11.36 & Very bad \\
\hline $\mathrm{Z7}$ & Fanhekou & 11.60 & Very bad \\
\hline Z8 & Zhu'er Mountain & 13.26 & Worse \\
\hline Z9 & Shifosi Reservoir & 12.48 & Very bad \\
\hline $\mathrm{Z} 10$ & Mahushan Bridge & 11.60 & Very bad \\
\hline Z11 & Juliuhe & 12.06 & Very bad \\
\hline $\mathrm{Z} 12$ & Yubaotai & 13.11 & Worse \\
\hline Z13 & Zaojiaoshu & 13.65 & Worse \\
\hline Z14 & Laodafang & 12.27 & Very bad \\
\hline Z15 & Manduhu & 12.52 & Very bad \\
\hline Z16 & Hongmiaozi & 12.74 & Very bad \\
\hline Z17 & Dazhang Bridge & 12.89 & Very bad \\
\hline Z18 & Sandaogou & 12.14 & Very bad \\
\hline Z19 & Lengdong Bridge & 11.88 & Very bad \\
\hline $\mathrm{Z} 20$ & Linfeng Bridge & 12.59 & Very bad \\
\hline $\mathrm{Z} 21$ & Shuguang Highway Rubber Dam & 13.11 & Worse \\
\hline $\mathrm{Z} 22$ & Zhaoquan River & 11.71 & Very bad \\
\hline Z23 & Red Beach & 12.99 & Very bad \\
\hline
\end{tabular}


and has been relatively disturbed by human activities during the recovery process, while the riparian zone is basically stable, and its natural habitat has been destroyed. The natural habitats of 6 sampling points were restored from very bad or worse to general state, some of which were disturbed by invasive species or influenced by human activities to a large extent, resulting in the decrease of vegetation coverage in their riparian zone and the disturbance of habitat function. Among the 23 sampling sites, the natural habitats of 4 riparian zones changed from very bad to worse. These 4 sampling sites were seriously affected by grazing, so their vegetation coverage was slightly lower. In addition, some riparian zones were seriously degraded by rainfall, which had a negative impact on riparian zones' habitat restoration process. In this study, only $17.39 \%$ of the natural habitats in the riparian zone remained undisturbed, and the two evaluation results showed that these sampling points' natural habitats' riparian zones were in very bad condition. Comparative analysis found that the four riparian zones where the natural habitats remain in their original state have been seriously affected by grazing activities, human activities, as well as shore breaking and erosion, while their habitat structure varies greatly and they have poor ecosystem functions, so these zones' natural habitats have not improved.

\section{Conclusions}

Based on the stabilization, buffering, service and biodiversity functions of riparian zones' natural habitats, we constructed a practical evaluation index for the Liao River reserve's riparian zones' natural habitat restoration, and formulated its appropriate evaluation standard. The comprehensive index method was used to evaluate the current and historical status of natural habitat restoration in the riparian zone of the Liao River's main stream (Fudedian to Red Beach estuary) in its reserve. Evaluation results from 2019 showed that the situation of the Liao River's mainstream's riparian zone's natural habitat is as follows: $21.74 \%$ of its possible extent was in an excellent state, $17.39 \%$ was in a good state, $26.09 \%$ was in a general state, $17.39 \%$ was in a worse state, and $17.39 \%$ was in a very bad state. Based on the evaluation results of the riparian zone's natural habitat from the historical data in 2012, $26.09 \%$ of the riparian zone's natural habitat in the Liao River's main stream in its reserve was in worse state, and $73.91 \%$ was in very bad state.

The natural habitat of $82.61 \%$ of the Liao River reserve's riparian zone improved, and the natural habitat of only 4 sampling sites remained unchanged. It can be seen that the implementation of natural sealing technology in the Liao River's reserve during the $12^{\text {th }}$ Five-Year Plan has resulted in improved vegetation coverage in the riparian zone and a significant increase in vegetation diversity. However, the Liao River's reserve currently has serious disturbances related to human activity, which include grazing and invasive species that affect part of the riparian zone. These problems influence the survival and development of local plant species, cause inefficient recovery of vegetation diversity, and block the restoration process of the Liao River reserve's banks' natural habitat. Based on this, we suggest that human activities in the Liao River reserve's closed area should be reduced as much as possible, grazing in the closed area should be eliminated, and the sustainable restoration of natural habitats in the reserve's riparian zone should be accelerated by artificial planting of plant species to improve the diversity of this zone's vegetation and change its soil structure.

\section{Acknowledgements}

The authors acknowledge the financial support from the Major Scientific and technological projects for Water pollution Control and Treatment (No. 2018ZX07601003-04), the Liaoning Natural Science Fund (No.2019ZD-0556), and the Ten Million Talents Project in Liaoning Province (2018).

\section{Conflict of Interest}

The authors declare no conflict of interest.

\section{References}

1. WANG Q, FAN Z.P., LI F.Y., JU W.P. River habitat quality assessment, water quality analysis and their response relation of Puhe River Basin. Chinese Journal of Ecology. 34 (2), 516, 2015.

2. RANDHIR T.O., EKNESS P. Water quality change and habitat potential in riparian ecosystems. Ecohydrology \& Hydrobiology. 13 (3), 192, 2013.

3. WISE M.J. A field investigation into the effects of anthropogenic disturbances on biodiversity and alien invasions of plant communities. Bioscene. 43 (2), 3, 2017.

4. FELD C.K., FERNANDES M.R., FERREIRA, M.T., HERING D., ORMEROD S.J., VENOHR M., GUTIERREZ-CANOVAS C. Evaluating riparian solutions to multiple stressor problems in river ecosystems - a conceptual study. Water research. 139, 381, 2018.

5. WANG Q., YUAN X.Z., LIU H., PANG X., WANG Z.J., ZHANG Y.G. Stream habitat assessment of Dong River, China, using River Habitat Survey method. Acta Ecologica Sinica. 34 (06), 1548, 2014.

6. DIXON I., DOUGLAS M., DOWN J., BURROWS D., TOWNSEND S. A rapid method for assessing the condition of riparian zones in the wet/dry tropics of northern Australia. In Proceedings of the Fourth Australian Stream Management Conference: Linking Rivers to Landscapes. Department of Primary Industries, Water and Environment, Hobart, Tazmania pp. 2005, 173, 2005. 
7. GONNZALEZ E., FELIPE-LUCIA M.R., BOURGEOISs B., BOZ B., NILSSON C., PALMER G., SHER A.A. Integrative conservation of riparian zones. Biological conservation. 211, 20, 2017.

8. VAlERO E., ALVAREZ X., PICOS J. An assessment of river habitat quality as an indicator of conservation status. A case study in the Northwest of Spain. Ecological Indicators. 57, 131, 2015.

9. GRIZZETTI B., LIQUETE C., PISTOCCHI A., VIGIAK O., ZULIAN G., BOURAOUI F., ROO A.D., CARDOSO A.C. Relationship between ecological condition and ecosystem services in European rivers, lakes and coastal waters. Science of the Total Environment. 671 (25), 452, 2019.

10. JANSSEN P., CAVAILLE P., BRAY F., EVETTE A. Soil bioengineering techniques enhance riparian habitat quality and multi-taxonomic diversity in the foothills of the Alps and Jura Mountains. Ecological Engineering. 133, 1, 2019.

11. HOU J.Y., ZHANG Y.L. Research on Ecological Health Evaluating System of Hunhe River Shenyang Section. Environmental Protection Science. 33 (3), 74, 2007.

12. MENG W., ZHANG N., ZHANG Y., ZHENG B.H. Integrated assessment of river health based on water quality, aquatic life and physical habitat. Journal of Environmental Sciences. 21 (8), 1017, 2009.

13. ADRIA L.B., LAURA C., XAVIER P.M., ANNA E., FERRAN P., CARLES F. Evaluating the use of Myotis daubentonii as an ecological indicator in Mediterranean riparian habitats. Ecological Indicators. 74, 19, 2017.

14. HALE R., REICH P., DANIEL T., LAKE P.S., CAVAGNARO T.R. Assessing changes in structural vegetation and soil properties following riparian restoration. Agriculture, Ecosystems \& Environment. 252, 22, 2018.

15. DIEHL R.M., WILCOX A.C., MERRITT D.M., PERKINS D.W., SCOTT J.A. Development of an eco-geomorphic modeling framework to evaluate riparian ecosystem response to flow-regime changes. Ecological Engineering. 123, 112, 2018.

16. BLUMETTO O., CASTAGNA A., CARDOZO G., GARCIA F., TISCORNIA G., RUGGIA A., SCARLATO S., ALBICETTE M.M., AGUERRE V., ALBIN A. Ecosystem Integrity Index, an innovative environmental evaluation tool for agricultural production systems. Ecological Indicators. 101, 725, 2019.

17. ARMAN Z., SALMIATI S., SAID M.I.M., ARIS A. Development of macroinvertebrate-based multimetric index and establishment of biocriteria for river health assessment in Malaysia. Ecological indicators. 104, 449, 2019.

18. WANG S., ZHANG Q., YANG T., ZHANG L.Q., LI X.P., CHEN J. River health assessment: Proposing a comprehensive model based on physical habitat, chemical condition and biotic structure. Ecological Indicators. 103, 446, 2019.

19. FU B.L., LI Y., WANG Y.Q., CAMPBELL A., ZHANG B., YIN S.B., ZHU H.L., XING Z.F., JIN X.M., Evaluation of riparian condition of Songhua River by integration of remote sensing and field measurements. Scientific reports. 7 (1), 1, 2017.

20. LIU H., CAI Y., YU M.Q., GONG L.T., AN S.Q. Assessment of river habitat quality in Yixing district of Taihu Lake basin. Chinese Journal of Ecology. 31 (5), 1288, 2012.

21. CAO L.J. Evaluation of habitat restoration in Liaohe reserve. Dalian Ocean University, Dalian, China. 2018.
22. LIN M.Y. Assessment of river habitat quality in Qingyihe basin and the relationship with land use. Nanjing University, Nanjing, China. 2018.

23. LI L.X., WANG R.J., GU B., HE Y.L., CHEN J.C. Changes in biodiversity during the succession of plant communities on the rocky slopes of mine in islands. Chinese Journal of Ecology. 33 (7), 1741, 2014.

24. QU X.H., WANG X.Y. Study on ecological restoration and vegetation reconstruction of riparian zone in Dalian. Technology and Economic Guide. 27 (20), 113, 2019.

25. ZHAO Z.M. The healthy riparian zone and its evaluation method research in Liao River reserve. Shengyang University, Shengyang, China. 2013.

26. ZHENG B.H., ZHANG Y., LI Y.B. Study of indicators and methods for river habitat assessment of Liao River basin. Acta Scientiae Circumstantiae. 027 (006), 928, 2007.

27. WANG D. Biological integrity assessment and ecological function regionalization in Liaohe consevation area. Shenyang Agricultural University, Shengyang, China. 2016.

28. SA R.L., LIIU L.S., HUO W.J., YIN S.H., LI Z.P. Evaluation of habitat quality of arid rivers in north China -- a case study of Guishui river. Journal of China Institute Water Resource and Hydropower Research. 17 (02), 81, 2019.

29. GAO M.H., WUREN Q.Q.G., BATEER., MU Y.H., WANG J., ZHAO H.R., MENG Q.T. Influences of Grazing on Plant Community Characteristics, Soil Microorganism and Soil Enzyme Activity. Bulletin of Soil and Water Conservation. 36 (5), 62, 2016.

30. WANG D.D., YANG K., CHE Y., LV Y.P. Reach-scale riparian comprehensive assessment for Suzhou Creek, Shanghai. Acta Ecologica Sinica. 30 (13), 3501, 2010.

31. YIN Y.L., WANG Y.Q., LI S.X., LIU Y., ZHAO W., MA Y.S., BAO G.S. Effects of enclosing on soil microbial community diversity and soil stoichiometric characteristics in a degraded alpine meadow. Chinese Journal of Applied Ecology 30 (1), 130, 2019.

32. LUO J.H. The diversity analysis of riparian vegetation, butterflies and ecological comprehensive evaluation under the near-natural ecological restoration. Northeast Normal University, Changchun, China. 2014.

33. ZHONG B., SUN G., CHEN D.M., ZHANG N.N. Effects of different restoration measures on soil microbial biomass carbon and nitrogen and soil enzymes in the process of restoration of the desertified grassland in Zoige. Ecology and Environmental Sciences. 26 (3), 392, 2017.

34. CHEN F., LU S., HU X., HU Q., FENG C., XU Q., CHEN N., NGO H.H., GUO H. Multi-dimensional habitat vegetation restoration mode for lake riparian zone, Taihu, China. Ecological Engineering. 134, 56, 2019.

35. HE C., WU S.X., HU C.H., YANG D., LIU S.J. Study on the relationship between soil moisture content and plant diversity in the gully of the Yuanmou dry-hot valley. Subtropical Soil and Water Conservation. 31 (1), 29, 2019.

36. ZHOU X., LI Y., ZHANG J., LIU B., WANG M., ZHOU Y., LIN Z., HE Z. Diversity, abundance and community structure of ammonia-oxidizing archaea and bacteria in riparian sediment of Zhenjiang ancient canal. Ecological Engineering. 90, 447, 2016.

37. TIAN G., VOSE J.M., COLEMAN D.C., GERON C.D., WALKER J.T. Evaluation of the effectiveness of riparian zone restoration in the southern Appalachians by assessing soil microbial populations. Applied Soil Ecology. 26 (1), 63, 2004. 
38. LI Y.L., ZHU B.L., WANG L., ZHAO R. Design and application of ecological environment quality evaluation systems based on comprehensive index method. Science of Surveying and Mapping. 30 (1), 89, 2005.

39. ZHANG L., CHEN N.L. Analysis of the impact of Jinwu expressway on the ecological environment based on the comprehensive index evaluation method. Environment and Sustainable Development. 044 (003), 137, 2019.

40. JANSSEN P., PIEGAY H., PONT B., EVETTE A. How maintenance and restoration measures mediate the response of riparian plant functional composition to environmental gradients on channel margins: Insights from a highly degraded large river. Science of the Total Environment. 656, 1312, 2019.

41. MACFARLANE W.W., GILBERT J.T., JENSEN M.L., GILBERT J.D., HOUGH-SNEE N., MCHUGH P.A., WHEATON J.M., BENNETT S.N. Riparian vegetation as an indicator of riparian condition: Detecting departures from historic condition across the North American West. Journal of environmental management. 202, 447, 2017. 